\title{
Factors influencing biomass and carbon storage potential of different land use systems along an elevational gradient in temperate northwestern Himalaya
}

\author{
Bhalendra Singh Rajput • D. R. Bhardwaj • \\ Nazir A. Pala
}

Received: 13 August 2015/Accepted: 19 April 2016/Published online: 29 April 2016

(C) The Author(s) 2016. This article is published with open access at Springerlink.com

\begin{abstract}
We observed the influence of five different altitudes and prevailing agro ecosystems on biomass and carbon sequestration potential in Kullu district of Himachal Pradesh, India. The study area had five prevailing land uses viz., agriculture, agro-horticulture, horticulture, silvi-pasture, and forest at four elevations representing about $1{ }^{\circ} \mathrm{C}$ temperature change. The results showed that maximum total biomass of $404.35 \mathrm{Mg} \mathrm{C}^{-1}$ was accumulated by forest landuse and followed a decreasing trend in the order as forest $>$ silvi-pasture $>$ agro-horticulture $>$ horticulture $>$ agriculture. Similar trends were also seen with respect to biomass carbon (C) density and $\mathrm{C}$-sequestration potential of different land uses. Biomass and carbon density potential enhanced with the increase in the altitudinal ranges from 1100-1400 to 2000-2300 $\mathrm{m}$ a.s.1. But, the rate of C-sequestration
\end{abstract}

B. S. Rajput

Department of Agronomy (Agroforestry), BHU, Rajiv Gandhi South Campus, Barkachha, Mirzapur, U.P., India e-mail: bhalendrasrajput@gmail.com

B. S. Rajput - D. R. Bhardwaj

Department of Silviculture and Agroforestry, Dr Y S Parmar University of Horticulture and Forestry, Solan, H.P., India

e-mail: bhardwajd_uhf@rediffmail.com

N. A. Pala $(\bowtie)$

Department of Forestry, Uttar Banga Krishi

Viswavidyalaya Pundibari, Cooch Behar, W.B., India

e-mail: nazirpaul@gmail.com potential enhanced from 1100 to $2000 \mathrm{~m}$ and declined at 2000-2300 m a.s.l. Maximum carbon density (393.29 $\mathrm{Mg} \mathrm{C} \mathrm{ha}^{-1}$ ) of both plant as well as soil was displayed by the forest-based land use systems situated at an altitudinal gradient of 2000-2300 m a.s.l. The rate of C-sequestration was maximum $\left(2.17 \mathrm{Mg} \mathrm{ha}^{-1}\right)$ in the agro-horticulture at 2000-2300 m a.s.l. This study brings out the potential of different land use systems influenced by varying factors on their C-sequestration potential in western Himalayan elevation gradient, thereby providing useful information for effective management in a climate change mitigation and carbon budget.

Keywords Biomass - Carbon density - Land use . Climate change $\cdot$ Himalaya

\section{Introduction}

Many environmental factors viz., temperature, precipitation, atmospheric pressure, solar radiation, and wind velocity change systematically with altitude. Therefore, altitudinal gradients are among the most powerful 'natural experiments' for testing ecological and evolutionary responses of biota to environmental changes (Korner 2007). Although changes in species composition and distribution, biodiversity, and community structure along altitudinal gradients have been well documented, the altitudinal patterns of carbon (C) storage in different land uses remain poorly 
studied (Zhu et al. 2010). A recent global assessment of the impacts of climate change suggests that during twenty-first century, mountain ecosystems experiences two to three times' greater rates of warming than during the twentieth century (Nogues-Bravo and Araiijo 2006).

Vegetation biomass is a crucial variable for understanding the potential future changes of the climate system. Depending on the quantity of biomass, vegetation cover can have a direct influence on local, regional, and even global climate, particularly on air temperature and humidity (Bombelli et al. 2009). Biomass and carbon storage in forest ecosystems play an important role in the global carbon cycle (Li et al. 2013; Zhao et al. 2014). Soil carbon, whereas, depends on the aboveground input received from plant litter and on the decomposition of fine roots belowground (Rasse et al. 2006). The aboveground tree biomass and belowground root biomass both need to be assessed to enable better estimations of total carbon (Hamburg 2000). Whereas, soil organic C-stock (SOC) exhibits considerable spatial variability both horizontally as well as vertically. The SOC diminishes with depth regardless of vegetation type and soil texture (Trujilo et al. 1997).

Major policy initiatives, including the National Forest Policy 1988, the National Agriculture Policy 2000, Planning Commission Task Force on Greening India 2001, National Bamboo Mission 2002, National Policy on Farmers, 2007 and Green India Mission 2010, emphasize the role of agroforestry for efficient nutrient cycling, organic matter addition for sustainable agriculture, and for improving vegetation cover (Rajput et al. 2015). As mountain regions cover about $27.2 \%$ of the global land area and there have been rapid climate changes in mountain regions during the past few decades (IPCC 2007) understanding the shifts in forest $\mathrm{C}$-storage and allocation along altitudinal gradients in mountain region will help us better predict the response of regional and global $\mathrm{C}$ balance to future climate change. Information on variation in biomass and $\mathrm{C}$-stocks along the altitudinal gradients in different land use types of the temperate region is still lacking. Keeping the above facts in view, the study was undertaken in Kullu district of Himachal Pradesh, which falls in temperate region of northwestern Himalaya with the objective of studying the biomass, C-stock, and C-sequestration potential of different land uses along an altitudinal gradient influenced by varying locality factors.

\section{Materials and methods}

Study area

The study was carried out in the mountainous region of Kullu district of Himachal Pradesh, India located between $31^{\circ} 58^{\prime} 00^{\prime \prime} \mathrm{N}$ latitude and $77^{\circ} 06^{\prime} 04^{\prime \prime} \mathrm{E}$ longitude. The district Kullu forms a transitional zone between the lesser and the greater Himalaya and presents a typical rugged mountainous terrain with moderate to high relief (Kumar 2010; Rajput et al. 2015). Climate varies from hot and dry at (1100-1800 m), moderate between 1800 and $2500 \mathrm{~m}$, and intensely cold between 2500 and $4300 \mathrm{~m}$ elevations. The monthly maximum and minimum temperature ranged between $8.5-31.8$ and $10-21.5^{\circ} \mathrm{C}$, respectively. The district receives moderate rainfall and bulk of it is received during the months of July, August, December, and January. Soil $\mathrm{pH}$ of the area ranges from 6.3 to 6.6 with entisols, inceptisols, and mollisol as the dominant soil types (Kumar 2010; Rajput et al. 2015). The forest in the study area comprised low Himalayan temperate forest, oak forest, upper west Himalayan temperate forest, low-level blue pine forest, west Himalayan high-level dry blue pine forest etc. (Champion and Seth 1968).

\section{Experimental methodology}

Four mountainous ranges having altitudinal ranges of 1100-2300 m a.s.l. were selected as replicates. Each range was then further divided into four altitudinal gradients viz., 1100-1400, 1400-1700, 1700-2000, and 2000-2300 $\mathrm{m}$ a.s.l. In each altitudinal range, five land use systems viz., agriculture, agro-horticulture, horticulture, silvi-pasture, and forests were selected. This experiment was laid out as randomized block design (factorial experiment), comprising 20 treatment combinations [5 (land use systems) $\times 4$ (altitudinal ranges)] having specific tree-crop combinations.

Estimation of vegetation biomass and soil carbon content

The entire trees falling in the plot $\left(50 \times 10 \mathrm{~m}^{2}\right)$ were enumerated. DBH (diameter at breast height) and height was measured with caliper and Ravi's multimeter, respectively. Local volume equation for specific tree species was used for calculating the volume. 
Wherever volume equation was not available for the species, form factor was calculated using Pressler (1865) and Bitterlich (1984). Specific gravity values were used to determine the biomass and stem cores were taken to find out specific gravity using maximum moisture method (Smith 1954). Total numbers of branches, irrespective of size were counted on each of the sample tree, and categorized on the basis of basal diameter into three groups, viz., $<6,6-10$, and $>10 \mathrm{~cm}$. Branch biomass and leaf biomass of forest tree species was measured by methods given by Chidumaya (1990) and Jenkins et al. (2003), respectively. Leaf carbon content was estimated by multiplying with a factor of 0.5 (IPCC default value). The total tree biomass was calculated as the sum of stem biomass, branch biomass, and leaf biomass. The tree biomass was converted into its carbon content by multiplying a factor of 0.5 (IPCC default value). Fruit tree root biomass was determined using the root-shoot (apple $=0.33$; plum $=0.35$ ) developed by Rajput et al. (2015).

Apple: $Y=1.052 X^{1.076}\left(R^{2}=0.823\right)$

Plum: $Y=0.008 X^{2}+1.86 X-0.754\left(R^{2}=0.894\right)$

Fallen leaves and pruned wood under each tree was collected, weighed, subsampled, and oven dried at $65 \pm 5{ }^{\circ} \mathrm{C}$ to a constant weight. Five plots of $1 \times 1 \mathrm{~m}^{2}$ were used for estimation of crop biomass. All the crop biomass occurring within the borders of the quadrates were cut at ground level and collected samples were weighed, subsampled, and oven dried at $65 \pm 5{ }^{\circ} \mathrm{C}$ to a constant weight. Belowground biomass of crops and grasses was calculated by multiplying aboveground biomass of crops/grasses with a factor of root:shoot ratio of particular crop/grass (Rajput et al. 2015). C-stock was obtained by multiplying the biomass with the IPCC default value (0.5) and $\mathrm{C}$-sequestration was calculated deducting the C-loss from the system through removal of biomass, fruit yield, or through pruned wood with the total C captured by plants.

Soil samples were collected, air dried in shade, grinded with wooden pestle, passed through $2 \mathrm{~mm}$ sieve, and stored in cloth bags for further laboratory analysis. The bulk density $\left(\mathrm{g} \mathrm{cm}^{-3}\right)$ and organic carbon content were estimated by the specific gravity method (Singh 1980) and Walkley and Black (1934) method, respectively. The soil organic C-stock for a specific depth was computed using the formulae given by Nelson and Sommers (1996). The bulk density and carbon concentration data were used to compute amounts of carbon per unit area of land use:

$$
\begin{aligned}
C\left(\mathrm{Mg} \mathrm{ha}^{-1}\right)=[ & \text { soil bulk density }\left(\mathrm{g} \mathrm{cm}^{-3}\right) \\
& \times \text { soil depth }(\mathrm{cm}) \times C(\%)] \times 100,
\end{aligned}
$$

where $C$ expressed in decimal fraction.

The data obtained were subjected to statistical analysis as per the procedure suggested by Gomez and Gomez (1984).

\section{Results and discussion}

Biomass production $\left(\mathrm{t} \mathrm{ha}^{-1}\right)$

Total highest biomass (404.35 $\mathrm{Mg} \mathrm{ha}^{-1}$ ) was reported in forest landuse, which is 3.5-4 times more than total biomass accumulation in other perennial componentbased land use systems viz., agro-horticulture, horticulture, silvi-pasture; and about 20 times more than annual cropping system i.e., agriculture (Table 1). Highest biomass stock $\left(\mathrm{Mg} \mathrm{ha}^{-1}\right)$ in the forest system may be because of age and tree density that ranged between 90-180 years and 190-650 trees per hectare, respectively. The average total biomass of forest ecosystem (404.35 $\mathrm{Mg} \mathrm{ha}^{-1}$ ) in the present study is on the higher side than other temperate and boreal forest ecosystems (326.0 Mg ha ${ }^{-1}$ ) of the world (Anonymous 1999). Higher biomass of our temperate forest ecosystem can be ascribed to low biotic interference and inaccessibility of these landscapes in the past. Whittaker and Marks (1975) cited biomass data for a number of temperate forests that indicated a range of aboveground biomass from 113 to $340 \mathrm{t} \mathrm{ha}^{-1}$ for mature pine-oak woodland and a mature spruce-fir forest, respectively. Total biomass production (Table 1) increased with altitudinal ranges from $1100-1400 \mathrm{~m}$ to $2000-2300 \mathrm{~m}$ a.s.l. The physiographic factors are widely known to show a major impact on plant microhabitat especially in hill slope form (Sharma et al. 2010). Biomass increased with increasing altitude in the present study is also supported by the reported values of Zhu et al. (2010) and Gairola et al. (2011). In our study area dominance of mature large conifers at higher altitude as compared to lower can explain the cause. Different treatment 


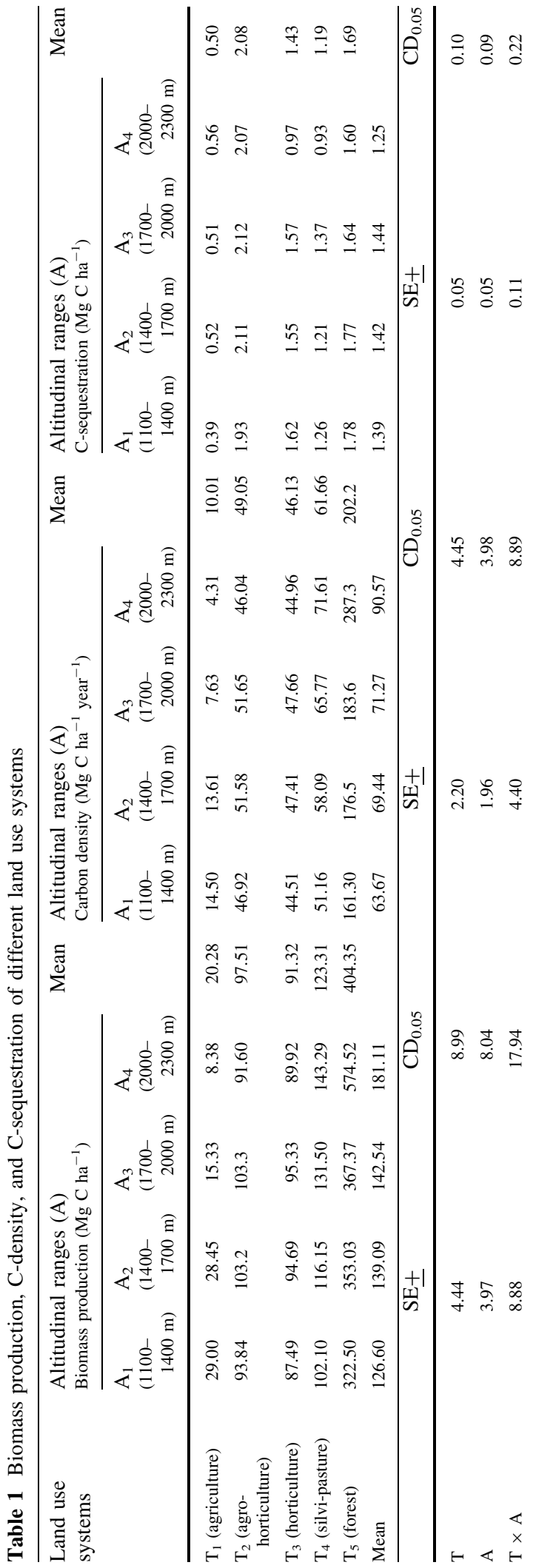

combinations of forest land use system and altitudinal gradient $\left(\mathrm{T}_{5} \mathrm{~A}\right)$ exhibited significantly higher values of biomass density in comparison to all other systems and the values of silvi-pasture and forest land use systems enhanced with the increasing altitudinal ranges (Tables 1).

Biomass carbon density of different land use systems

Maximum biomass carbon density in the forest land use system differed significantly $(P<0.05)$ from other land use systems and followed the trend: forest $>$ silvipasture $>$ agro-horticulture $>$ horticulture $>$ agriculture (Table 1). Higher carbon density of the perennial component-based land use systems can be attributed to continuous accumulation of carbon in the woody component. The biomass carbon storage capacity (49.05 $\mathrm{Mg} \mathrm{C} \mathrm{ha}{ }^{-1}$ ) as calculated in our fruit-based temperate agroforestry system is similar to the value reported by Sanneh (2007) for fruit-based agroforestry systems $\left(51.85 \mathrm{Mg} \mathrm{ha}^{-1}\right)$ of wet temperate northwestern Himalaya. The total biomass carbon storage potential $\left(202.2 \mathrm{Mg} \mathrm{ha}^{-1}\right)$ recorded in the present study is almost same (i.e. $190 \mathrm{Mg} \mathrm{C} \mathrm{ha}^{-1}$ ) as given by Singh et al. (1994) for Himalayan forest and by Sanneh (2007) for wet temperate Himalayan forest (185.0 $\mathrm{Mg} \mathrm{C} \mathrm{ha}^{-1}$ ). But, the value is on higher side in comparison to the average value of 160.0 $\mathrm{Mg} \mathrm{C} \mathrm{ha}^{-1}$ given by Houghton (1995) for world's temperate forest ecosystems. This variation can mainly be due to difference in the nature of the temperate forest ecosystems as average annual temperature of Himalayan forest (warm temperate) is higher than the temperate forest found in other parts of the world. The biomass carbon density increased with increasing altitudinal ranges from $1100-1400$ to 2000-2300 m a.s.1. The altitudinal range of 2000-2300 $\mathrm{m}$ a.s.l. displayed maximum biomass density (90.57 Mg C ha ${ }^{-1}$ ) and is significantly higher than other altitudinal ranges. In the interaction effect, maximum carbon density (287.3 $\mathrm{Mg} \mathrm{C} \mathrm{ha}^{-1}$ ) is found on elevation range of 2000-2300 $\mathrm{m}$ a.s.l. (Table 1).

\section{Rate of C-sequestration}

Maximum rate of $\mathrm{C}$-sequestration potential (2.08 Mg C ha-1 year $^{-1}$ ) has been found in agro- 
horticulture system followed by forest $(1.69 \mathrm{Mg}$ $\mathrm{ha}^{-1}$ year $^{-1}$ ), horticulture (1.43 $\mathrm{MgC} \mathrm{ha}^{-1}$ year $^{-1}$ ), silvi-pasture (1.19 $\mathrm{Mg} \mathrm{C}^{-1}$ year $^{-1}$ ), and agriculture (0.50 Mg C ha year $^{-1}$ ), respectively (Table 1). The estimate of $\mathrm{C}$-sequestration potential in agroforestry systems are highly variable, ranging from 0.29 to 15.21 Mg C ha ${ }^{-1}$ year $^{-1}$ (Nair et al. 2009), depending on the site characteristics, land use types, species involved, stand age, and management practices. Maximum C-sequestration potential is displayed by agrohorticulture land use system situated at the altitudinal range of 2000-2300 m a.s.l and minimum by agriculture land use system at the altitudinal range of 1100-1400 $\mathrm{m}$ a.s.1. The rate of C-sequestration potential in fruit-based agro-horticulture land use is higher than all combinations of forests, silvi-pasture systems. This is because of the fact that agriculture crops are put to intensive management practices resulting into their higher biomass production but whatever produced is removed annually from the system leading to their lower sequestration potential. Whereas, in fruit-based agroforestry systems, which are again put to intensive management, the biomass keep on piling year after year in fruit trees, and only pruned wood and fruits are removed annually resulting into their higher C-sequestration potential.

Soil organic carbon $(\%)$

Maximum organic carbon $(2.5 \%)$ is found in the forest system followed by agri-horticulture $(0.89 \%)$, horticulture $(0.87 \%)$, silvi-pasture $(0.81 \%)$, and agriculture $(0.68 \%)$ in the descending order (Fig. 1). Leaf litter and root litter input play a major role in

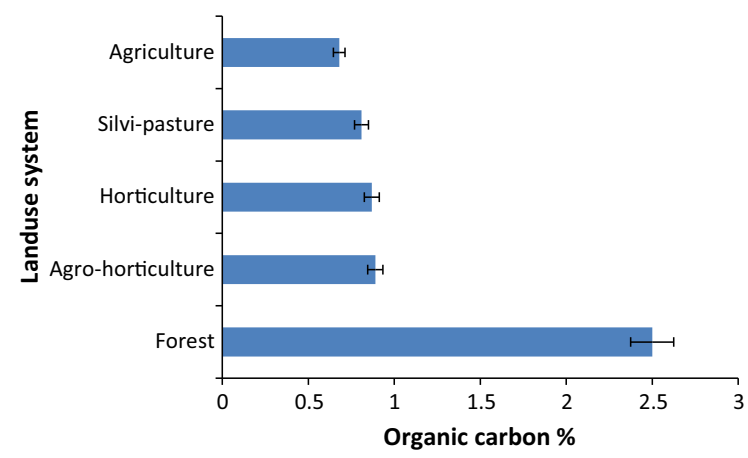

Fig. 1 Organic carbon (\%) in different land use systems across the study area forest soil, while agricultural practices such as tillage, FYM, fertilizer inputs, and the return of crop residues determine the SOC dynamics in cultivated soils. Significant increase in organic carbon content in soils under tree-based land use systems may be ascribed to more leaf litter deposition followed by decomposition and root turnover from trees (Rhodes 1995). The maximum accumulation of soil organic carbon $(1.32 \%)$ is in the surface layer $(0-20 \mathrm{~cm})$, and decreased to $0.98 \%$ at $20-40 \mathrm{~cm}$ depth. The greater accumulation of soil organic carbon on the surface is due to the greater incorporation of leaf litter on it. The findings are supported by the results of Minhas et al. (1997) and Shah et al. (2013) for Himalayan region. The organic matter has a significant positive correlation $\left(r^{2}=0.77\right)$ with altitude (Banerjee et al. 1998). In our study (Fig. 2), we also found that the organic carbon increased with increasing altitudinal ranges, which can be owed to continuous accumulation of leaf litter and slower decomposition rate at higher altitude than at lower ones. The increase in organic matter with altitude has also been reported by Minhas and Bora (1982) in soil profiles of Himachal Pradesh.

Soil organic carbon pool inventory $\left(\mathrm{Mg} \mathrm{ha}^{-1}\right)$

Maximum soil organic pool in 0-40 cm layer has been recorded in forest system $\left(98.08 \mathrm{Mg} \mathrm{ha}^{-1}\right)$, followed by agro-horticulture $\left(41.05 \mathrm{Mg} \mathrm{ha}^{-1}\right)$, horticulture (39.16 $\left.\mathrm{Mg} \mathrm{ha}^{-1}\right)$, silvi-pasture $\left(35.79 \mathrm{Mg} \mathrm{ha}^{-1}\right)$, and agriculture $\left(33.88 \mathrm{Mg} \mathrm{ha}^{-1}\right)$, respectively in the descending order. In general, soil organic C-stock in the $0-40 \mathrm{~cm}$ depth showed an increasing trend with increasing altitudinal ranges, except a slight dip at

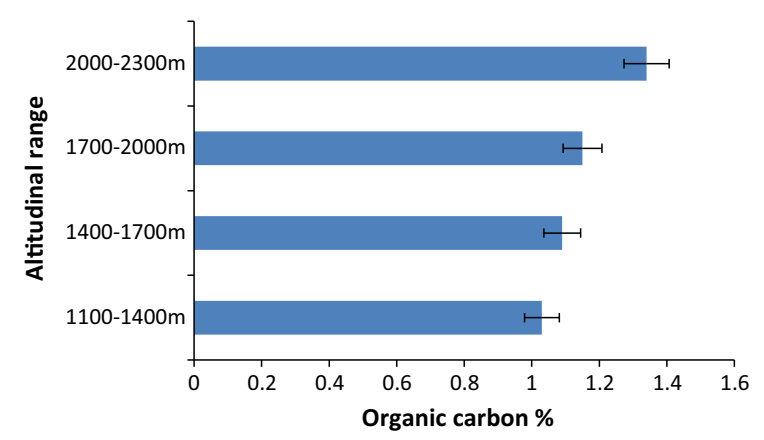

Fig. 2 Altitude-wise status of organic carbon (\%) in the study area 
1700-2000 m elevation range. Perennial plant-based land use systems viz., agri-horticulture, silvi-pasture, horticulture, and forest use systems have displayed higher C-stock than in soils (Table 2). Whereas, in the annual or agriculture-based land use system, the $\mathrm{C}$-stock is higher in soil than in the plant pool. These findings agree with the findings of Houghton (1995) and Sanneh (2007) implying that these ecosystems need to be protected and conserved.

Total C-stock $\left(\mathrm{Mg} \mathrm{ha}^{-1}\right)$

Mean total C-stock (303.39 $\mathrm{Mg} \mathrm{C} \mathrm{ha}{ }^{-1}$ ) is maximum in the forest system, which is around 2.5-4 times higher than perennial plant-based systems (Table 2). The average total $\mathrm{C}$-stock of the forest in the mountainous ecosystem is $303.39 \mathrm{Mg} \mathrm{C} \mathrm{ha}^{-1}$, which is slightly higher than reported by Houghton (1995) for temperate evergreen forest (294.1 $\mathrm{Mg} \mathrm{C} \mathrm{ha}^{-1}$ ). The C-sequestration potential of our horticulture-based land use systems ranged between 72.8 and $80.1 \mathrm{Mg} \mathrm{C}^{-1}$. The C-sequestration potential of tropical agroforestry was estimated between 12 and $228 \mathrm{Mg} \mathrm{C}^{-1}$ with a medium value of $95 \mathrm{Mg} \mathrm{C} \mathrm{ha}^{-1}$ by Albrecht and Kandji (2003).

The data presented in the Table 2 reveal that as we moved from lower elevation range (1100-1400 m) to higher elevation range $(1700-2000 \mathrm{~m})$, the ratio between soil and plant kept on increasing and further slightly decreased at (2000-2300 m) elevation range. Increasing soil-plant ratio indicates greater vulnerability of the soil pool to $\mathrm{CO}_{2}$ emission. If in future temperature increases then there will be net emission of $\mathrm{CO}_{2}$ from soil into the atmosphere, because of greater mineralization from the soil and this emission rate will be higher between 1400-1700 and 1700-2000 m a.s.l. altitudinal ranges. This shift between one altitudinal range to another altitudinal ranges signifies the difference of approximately $\mathrm{I}{ }^{\circ} \mathrm{C}$. In the mountainous ecosystem, elevation range of 2000-2300 m a.s.l. shows a higher total carbon density level in all the land use systems. Thus, this elevation range also needs greater attention from environmental point of view.

\section{Conclusion}

The land use systems viz., forest and silvi-pasture particularly at higher elevations is store house of 
C-stocks in both plant as well as soil, which needs to be conserved for environmental protection. From carbon dioxide mitigation point of view, agro-horticulture land use systems are found better than agriculture, horticulture, silvi-pasture, and forest land use systems at all the altitudinal gradients. It shows that fruit-based systems that are a common land use in many parts of the temperate ecosystem including Himalayan region with a significant economic, nutritional, and food security role can also provide an important environmental service through mitigation of atmospheric $\mathrm{CO}_{2}$. In a broader context, these results have implications on the role of tree-based systems in greenhouse mitigation through soil and plant carbon storage. The results of the present study will be helpful for understanding the pattern of C-storage and C-sequestration potential in various land uses of temperate regions in other parts of Himalayan region having similarity in locality factors.

Open Access This article is distributed under the terms of the Creative Commons Attribution 4.0 International License (http:// creativecommons.org/licenses/by/4.0/), which permits unrestricted use, distribution, and reproduction in any medium, provided you give appropriate credit to the original author(s) and the source, provide a link to the Creative Commons license, and indicate if changes were made.

\section{References}

Albrecht A, Kandji ST (2003) Carbon sequestration in tropical agroforestry systems. Agric Ecosyst Environ 99:15-27

Anonymous (1999) State of forest report-Govt. of India: forest survey of India. Ministry of Environment and Forests, Dehradun, pp 49-52

Banerjee SK, Gupta RD, Jha MN, Das TH (1998) Status, nature and characteristics of soil organic matter in Himalayan and sub-Himalayan region. Bull Indian Soc Soil Sci 19:14-30

Bitterlich W (1984) Relaskop idea slough: commonwealth Agricultural Bureaux. Farnham Royal, Slough

Bombelli A, Avitabile V, Balzter H (2009) Biomass. In: di Caracalla VDT (ed) Assessment of the status of the development of the standards for the terrestrial essential climate variables (T12). Global Terrestrial Observing System, Rome

Champion HG, Seth SK (1968) A revised survey of the forest types of India. Government of India Press, New Delhi

Chidumaya EN (1990) Above ground woody biomass structure and productivity in Zambezian Woodland. For Ecol Manage 36:33-46

Gairola S, Sharma CM, Ghildiyal SK, Suyal S (2011) Live tree biomass and carbon variation along an altitudinal gradient in moist temperate valley slopes of the Garhwal Himalaya (India). Curr Sci 100:1862-1870
Gomez KA, Gomez AA (1984) Statistical procedure for agriculture research, 2nd edn. Wiley, New York

Hamburg SP (2000) Simple rules for measuring changes in ecosystem carbon in forestry-offset projects. Mitig Adapt Strat Glob Change 5:25-37

Houghton RA (1995) Changes in the storage of terrestrial carbon since 1850. CRC/Kewis Publishers, Boca Raton

IPCC (2007) Climate change 2007: the physical science basis. Cambridge University Press, Cambridge

Jenkins JC, Chojnacky DC, Heath LS, Bridsey RA (2003) National scale biomass estimation for United States tree species. For Sci 49:12-35

Korner C (2007) The use of altitude in ecological research. Trends Ecol Evol 22:569-574

Kumar A (2010) Hydrological conditions of River Beas and its fish fauna in Kullu Valley, Himachal Pradesh, India. Environ Conserv J 11(3):7-10

Li C, Zha T, Liu J, Jia X (2013) Carbon and nitrogen distribution across a chronosequence of secondary lacebark pine in China. For Chron 89(2):192-198

Minhas RS, Bora NC (1982) Distribution of organic C and the forms of nitrogen in topographic sequence of soils. J Indian Soc Soil Sci 30:135-139

Minhas RS, Minhas H, Verma SD (1997) Soil characterization in relation to forest vegetation in the wet temperate zones of Himachal Pradesh. J Indian Soc Soil Sci 45(1):146-151

Nair PKR, Kumar BM, Nair VD (2009) Agroforestry as a strategy for C-sequestration. J Soil Sci Plant Nutr 172:10-23

Nelson DW, Sommers LE (1996) Total carbon, organic matter. In: Sparks DL (ed) Method of soil analysis-part 3: chemical methods. Soil Science Society of America Inc., Madison, pp 961-1010

Nogues-Bravo D, Araiijo M (2006) Exposure of global mountain systems to climate warming during the 21 st century. Glob Environ Change Human Policy Dimens 1:420-428

Pressler M (1865) Das Gesetz der Stambildung Leipzig, pp 153

Rajput BS, Bhardwaj DR, Pala NA (2015) Carbon dioxide mitigation potential and carbon density of different land use systems along an altitudinal gradient in north-western Himalayas. Agroforest Syst. doi:10.1007/s10457-015-9788-8

Rasse DP, Mulder J, Moni C, Chenu C (2006) Carbon turnover kinetics with depth in a French loamy soil. Soil Sci Soc Am J 70(6):2097-2105

Rhodes C (1995) Seasonal pattern of nitrogen mineralization and soil moisture beneath Faidherbia albida (syn. Acacia albida) in Central Malawi. Agroforest Syst 29:133-145

Sanneh A (2007) Status of C-stockunder different landuse systems in wet temperate north western Himalaya. M.Sc. Thesis, Dr Y.S. Parmar University of Horticulture and Forestry, Nauni, Solan

Shah S, Sharma DP, Pala NA, Tripathi P, Dar MA (2013) Carbon stock and density of soils under chir pine (Pinus roxburghii Sargent) forests of Solan forest division, Himachal Pradesh. Ind J Soil Conserv 41(3):279-286

Sharma CM, Gairola S, Ghildiyal S (2010) Physical properties of soils in relation to forest composition in moist temperate valley slopes of the Central Western Himalaya. J For Sci 26:117-129

Singh RA (1980) Soil physical analysis. Kalyani Publishers, New Delhi, pp 61-62 
Singh SP, Adhikari BS, Zobel DB (1994) Biomass, productivity, leaf longevity and forest structure in the central Himalaya. Ecol Monogr 64:401-421

Smith DM (1954) Maximum moisture content method for determining specific gravity of small wood samples. Forest Products Laboratory, Madison

Trujilo W, Amezquita E, Fisher MJ, Lal R (1997) Soil organic carbon dynamics and land use in the Colombian savannas I. Aggregate size distribution. In: Lal R, Kimble JM, Follett $\mathrm{RF}$, Stewart BA (eds) Soil processes and the carbon cycle. CRC Press, Boca Raton, pp 267-280

Walkley AJ, Black A (1934) Estimation of soil organic carbon by chromic acid titration method. Soil Sci 37:29-38
Whittaker RH, Marks PL (1975) Methods of assessing terrestrial productivity. In: Lieth $\mathrm{H}$, Whittaker $\mathrm{RH}$ (eds) Primary productivity of the biosphere. Springer-Verlag, Berlin, pp 56-118

Zhao J, Kang F, Wang L, Yu X, Zhao W, Song X, Zhang Y, Chen F, Sun Y, He T, Han H (2014) Patterns of biomass and carbon distribution across a chronosequence of Chinese pine (Pinus tabulaeformis) forests. PLoS One 9(4):e94966. doi:10.1371/journal.pone.0094966

Zhu B, Wang X, Fang J (2010) Altitudinal changes in carbon storage of temperate forests on Mt Changbai, Northeast China. J Plant Res 123:439-452 